\title{
A Brief Survey of Mycophagy in Ruffed Grouse, Bonasa umbellus, from Northwestern Ontario
}

\author{
Joey B. TANNEY ${ }^{1}$ and LeONARD J. HutCHISON ${ }^{1}$ \\ ${ }^{1}$ Faculty of Natural Resources Management, Lakehead University, 955 Oliver Road, Thunder Bay, Ontario P7B 5E1 Cana- \\ da; e-mail: jtanney@lakeheadu.ca.
}

Tanney, Joey B., and Leonard J. Hutchison. 2011. A brief survey of mycophagy in Ruffed Grouse, Bonasa umbellus, from northwestern Ontario. Canadian Field-Naturalist 125(1): 72-73.

There are few published observations regarding the phenomenon of mycophagy in birds, the Ruffed Grouse being no exception. Twenty hunter-killed Ruffed Grouse crops were acquired in the Thunder Bay District from 22 September to 18 October, 2010, and examined for the presence of consumed fungal tissue. Four crops were found to contain intact remains of fruiting bodies. Based on cystidia and spore morphological characters, the specimens recovered were found to belong to three genera: Lactarius, Russula, and Melanoleuca. The results of this brief survey suggest the possible importance of mycophagy in the seasonal diet of the Ruffed Grouse, and indicate the need for further investigation.

Key Words: Ruffed Grouse, Bonasa umbellus, mushrooms, Lactarius, Russula, Melanoleuca, Ontario.

The Ruffed Grouse (Bonasa umbellus L.) is one of the most important game birds across its North American range (Rusch et al. 2000; Fearer and Stauffer 2003). Consequently, many studies have investigated the seasonal variation and composition of the Ruffed Grouse diet in various localities (e.g., Gilfillan and Bezdek 1944; Korschgen 1966; King 1969; Stafford and Dimmick 1979; Norman and Kirkpatrick 1984; Servello and Kirkpatrick 1989; Sedinger 1997). A noticeable gap in the literature is the lack of information pertaining to the use of fungal fruiting bodies by the Ruffed Grouse, most attention being paid to the consumption of plant material including herbaceous plants, berries, and reproductive buds. The few publications which include nominal observations of mycophagy in Ruffed Grouse ultimately ignore the possible significance of fungi in their diet.

Brown (1946) reported gilled mushrooms (Agaricales) in $5(2.6 \%)$ out of a total 188 crops obtained in Maine during a fall season. Based on a survey of 34 crops and gizzards collected in Maine in October, Kittams (1943) found that fungi composed $2.4 \%$ of the total food groups observed. In a similar study, 1 (2.0\%) out of 49 crops collected in interior Alaska during the fall contained Basidiomycete mushrooms (McGowan 1973). Conversely, Stewart (1956) found that gilled mushrooms were consumed in fair quantities by Ruffed Grouse chicks in the late summer. These occurrences of mycophagy in the summer and fall seasons offer evidence of the possible importance of mushrooms as a seasonal food. However, none of these studies actually identified the mushrooms to genus found in the digestive tracts, contributing to the ambiguity surrounding fruiting body selection by Ruffed Grouse.

From 22 September to 18 October, 2010, twenty hunter-killed Ruffed Grouse crops were acquired in the Thunder Bay District (northwestern Ontario) and examined for the presence of consumed fungal tissue. Four crops $(20 \%)$ were found to contain intact remains
TABLE 1. Fruiting bodies collected from Ruffed Grouse crops in the Thunder Bay District of northwestern Ontario.

\begin{tabular}{lcl}
\hline \hline Genus & Incidence (\# crops) & Date Collected \\
\hline Lactarius & 1 & $01 / 10 / 2010$ \\
Melanoleuca & 1 & $22 / 09 / 2010$ \\
Russula sp. 1 & 1 & $08 / 10 / 2010$ \\
Russula sp. 2 & 1 & $14 / 10 / 2010$ \\
\hline \hline
\end{tabular}

of fruiting bodies, which were subsequently collected and preserved in vials containing $70 \%$ ethanol. Gill tissue was mounted in various dyes, including Melzer's reagent, Phloxine B (1\% aqueous solution), and lactophenol cotton blue, to facilitate identification based on spore and fruiting body morphology. Specimens were viewed with a Nikon Eclipse E400 phase contrast compound light microscope and measurements were made on material mounted in Phloxine B.

The four fruiting bodies recovered belonged to three genera (Table 1). Identification to species was not possible based on the available tissue or microscopic characters alone; however, the two Russula specimens were represented by two distinct species. Members of the Russulaceae were distinguished by amyloid reticulate or wart ornamented basidiospores and cystidial morphology (Kränzlin 2005). The Lactarius specimen bore numerous lactiferous hyphae in the hymenium. Cystidial morphology and verrucose ornamentation on amyloid basidiospores aided in the identification of the Melanoleuca specimen (Gillman and Miller 1977).

Fungal material found in crops consisted of hymenia or gill tissue, with very little pileus or stipe tissue observed. This suggests the preferential feeding on gills rather than the consumption of entire fruiting bodies. The hymenium may be the most nutritious portion of the fruiting body due to the presence of relatively nitrogen-rich spores. Picking at the gills may also be easier than attempting to break whole caps for consumption. 
Despite the small sample size and inherent limitations involved with investigating diet composition based on crop analyses, which only represent recent feedings, it is evident that Ruffed Grouse in northwestern Ontario utilize fungi as a source of food in the fall season. When leafy plant tissue and berries become scarce in the fall, mushrooms may offer a high carbohydrate and protein source in a diet which is being replaced with lower-energy, fibrous foods (e.g., Lundgren 2009).

Reports of avian mycophagy are relatively scarce (Simpson 1998; Simpson 2000). Although this may reflect the actual rarity of this phenomenon, it could possibly be attributed to a lack of expertise in identifying fungi by researchers. Being able to recognize fungal tissue in gut contents and collaborating with mycologists may assist in the elucidation of mycophagy in birds, which may be more common than previously thought. We believe this note represents the first work identifying fungal genera consumed by Ruffed Grouse. Further work should include a larger sample size, longer sample period and the use of molecular techniques to more precisely identify the fungal diet composition. Investigating the effect of digestive tract passage on spore viability may also provide insight on the role of birds as possible spore dispersal vectors.

\section{Literature Cited}

Brown, C. P. 1946. Food of Maine Ruffed Grouse by seasons and cover types. Journal of Wildlife Management 10: 1728.

Fearer, T. M., and D. F. Stauffer. 2003. Relationship of Ruffed Grouse (Bonasa umbellus) home range size to landscape characteristics. American Midland Naturalist 150: 104-114.

Gilfillan, M. C., and H. Bezdek. 1944. Winter foods of the Ruffed Grouse in Ohio. Journal of Wildlife Management 8: $208-210$.

Gillman, L. S., and O. K. Miller. 1977. A study of the boreal, alpine, and arctic species of Melanoleuca. Mycologia 69: 927-951.
King, R. D. 1969. Spring and summer foods of Ruffed Grouse on Vancouver Island. Journal of Wildlife Management 33: 440-442.

Kittams, W. H. 1943. Foods of Ruffed Grouse in Maine. Journal of Wildlife Management 7: 231-233.

Korschgen, L. J. 1966. Foods and nutrition of Ruffed Grouse in Missouri. Journal of Wildlife Management 30: 86-100.

Kränzlin, F. 2005. Fungi of Switzerland. Volume 6. Russulaceae. Verlag Mykologia, Luzern, Switzerland.

Lundgren, J. G. 2009. Relationships of Natural Enemies and Non-Prey Foods. Progress in Biological Control. Volume 7. Springer Verlag, Dordrecht, The Netherlands. [pages 243-258].

McGowan, J. D. 1973. Fall and winter foods of Ruffed Grouse in interior Alaska. The Auk 90: 636-640.

Norman, G. W., and R. L. Kirkpatrick. 1984. Foods, nutrition, and condition of Ruffed Grouse in southwestern Virginia. Journal of Wildlife Management 48: 183-187.

Rusch, D. H., Destefano, M. C. Reynolds, and D. Lauten. 2000. Ruffed Grouse, Bonasa umbellus in The Birds of North America number 515. Edited by A. Poole and F. Gill. The Birds of North America, Inc., Philadelphia, Pennsylvania.

Sedinger, J. S. 1997. Adaptations to and consequences of an herbivorous diet in grouse and waterfowl. The Condor 99: 314-326.

Servello, F. A., and R. L. Kirkpatrick. 1989. Regional variation in the nutritional ecology of Ruffed Grouse. Journal of Wildlife Management 51: 749-770.

Simpson, J. A. 1998. Why don't more birds eat more fungi? Australasian Mycological Newsletter 17: 67-68.

Simpson, J. A. 2000. More on mycophagous birds. Australasian Mycologist 19: 49-51.

Stafford, S. K., and R. W. Dimmick. 1979. Autumn and winter foods of Ruffed Grouse in the southern Appalachians. Journal of Wildlife Management 43: 121-127.

Stewart, R. E. 1956. Ecological study of Ruffed Grouse broods in Virginia. The Auk 73: 33-41.

Received 6 November 2010

Accepted 29 November 2010 